\section{Arshinnikov D., Sviderskiy V., Myronyuk 0., Baklan D.}

\title{
INVESTIGATION OF THE MODIFICATION PROCESS OF NATURAL SEDIMENTARY CALCITE BY ORGANOSILICON COMPOUNDS
}

Встановлено, що в ході механохімічної активащї в присутності кремнійорганічних модифікаторів коефіщієнт гідрофільності поверхні осадової крейди знижується. Встановлено, що в присутності модифікаторів активізується аморфізація карбонатної сировини. Доведено, що модифікація поверхні осадової крейди знижує ємність адсорбційного шару. Визначено, що при модифікації знижується міцність структури в системі наповнювач-плівкоутворювач.

ключові слова: система наповнювач-плівкоутворювач, осадовий кальцит, механохімічна активація кремнійорганічними сполуками.

\section{Introduction}

The use of fillers in protective and decorative paint and varnish materials allows to significantly reduce their cost price, as well as to achieve improved performance characteristics such as crack resistance, strength, barrier properties, corrosion resistance, and so on. As fillers are often natural minerals of carbonate and silicate types: calcite, dolomite, kaolin, etc. And micronized calcite is the most common filler. The use of this filler is explained, on the one hand, by relative inactivity and by the absence of a significant deterioration in the properties of composites, and on the other hand by the stability of the quality of this material. The cost of this type of raw material, however, increases if it is imported, as it happens with different brands of micronized calcite in Ukraine. The main source of micronized calcite for the domestic market of the country is the companies Omya (Switzerland), Som Calcite (Turkey). At the same time, a number of deposits of sedimentary calcite are located on the territory of Ukraine, which can potentially be used in the production of coatings.

Sedimentary calcite differs from micronized volcanic with a lower perfection of the crystal structure and the presence of impurities, including coloring. Purification of the raw material from these impurities (for example, reprecipitation) significantly increases the cost of the material and is justified only in the production of functional fillers. However, even a material with an insufficient degree of whiteness can be used as filler for a wide range of protective coatings: primers and enamels for metal painting, materials for external work, etc.

An essential shortage of sedimentary materials therefore remains the high adsorption capacity due to their increased amorphousness with respect to the binder, as well as increased hygroscopicity. Elimination of these shortcomings will increase the attractiveness of Ukrainian carbonate raw materials for use in a number of paint and varnish materials.

In this regard, relevant studies are devoted to solving the problems of increased adsorption capacity of calcitebased carbonate fillers with respect to the binder, as well as increasing the affinity of their surface to polymer filmformers. When developing the technology for the modification of carbonate fillers, it is necessary to take into account the peculiarities of their mineralogical composition and crystalline structure, which is the determining factor of technical properties.

\section{The object of research and its technological audit}

The object of this research is the process of natural sedimentary calcite modification. The main problems that need to be solved in this research are the choice of the most suitable low-molecular modifier, as well as the selection of the optimum grinding regimes for the raw mineral. This is due to the fact that the interaction of the complex of organosilicon modifiers with carbonate surfaces has not been studied thoroughly enough, in contrast to their interaction with long-chain fatty acids. Also, despite a number of works devoted to the mechanoactivation of fillers, the question of the optimality of the chosen regime remains open.

To determine the features of the processes of mechanochemical activation of carbonate fillers in the presence of organosilicon compounds, a laboratory experiment has been put in place to optimize the quality of the product according to the criteria for interaction with a silicone film former. The aim of this experiment is determination of the following process parameters:

- efficiency of the change in the energy state of cal-

cium carbonate surface during the processing of its surface by modifiers;

- efficiency of modifiers, depending on the chemical composition; modes of mechanochemical activation.

A feature that at the moment makes unattractive the use of natural sedimentary calcite in the production of coatings is its high hygroscopicity, as well as its insufficient compatibility with the polymer film former. To eliminate this disadvantage, it is proposed to use mechanical activation together with the modification of its surface by organosilicon compounds. 


\section{The aim and objectives of research}

The aim of research is selection of the optimal modifier for natural sedimentary calcites of Ukrainian origin, as well as to determine the appropriate modes of mechanical activation of these minerals during the treatment with a modifier. Achieving this aim will allow using the raw material base of Ukraine for the production of a number of paint and varnish materials.

To achieve this aim, it is necessary to solve the following tasks:

1. To determine the degree of change in the surface properties of natural sedimentary calcite, depending on the type of functional groups of the modifier.

2. To determine the effect of the modifier on the grinding processes of raw calcium carbonate.

3. To study the patterns of interaction between the surface of modified calcite and the silicone film former.

\section{Research of existing solutions of the problem}

To improve compatibility with the polymer matrix, the calcite surface is treated with modifiers based on aliphatic fatty acids, silanes, phosphates and titanates [1]. Modifiers of the first type, namely stearic acid, are the most common and, therefore, well-studied, which is reflected in the number of papers devoted to this process [2-4]. Modifiers of other types are used less often, but often are specific for those polymers in whose matrices it is planned to further use the modified filler. Thus, in work [5] the process of processing calcium carbonate is described by the product of modification of low-molecular polyethylene with maleic anhydride. The material is intended for use as a filler of extrusion polyethylene [6] describes the use of alkoxysilanes for the modification of calcium carbonate nanoparticles. It is also noted that with the help of silanes, the energy of the surface of the calcite particles can be flexibly regulated, while using stearic acid it is possible only to reduce the polarity of the calcite surface to a fixed level. The latter can be a problem when introducing modified carbonate filler into mid-polar polymer matrices, for example, styrene-butadiene rubber, as well as acrylic rubbers. Similar problems arise with the use of stearic acid with medium-polar film-forming agents for paint and varnish materials. Similar results are obtained when surface treatment with silane modifier in the presence of phosphoric acid [7].

The use of mechanochemical activation to intensify the processes of surface treatment of calcium carbonate particles is described in $[8,9]$. It is pointed out that when the mechanical factor and the chemical modifier are combined, it is possible to increase the uniformity of the obtained product, as well as to increase the degree of hydrophobicity of calcite. The decrease in the required amount of stearic acid by grinding is also noted in [1], however, this error is due to an incorrect determination of the equilibrium adsorption of stearic acid by the studied material. It is known [10] that there is a certain optimum in terms of the time of mechanical processing of materials. And the position of this optimum is determined by the rate of amorphization processes, as well as the course of polymorphic transformations of minerals during grinding.

In this regard, promising are the studies devoted to the selection of the most suitable modifier of sedimentary calcite surface from a set of functional silicone compounds, as well as the establishment of an effective regime of mechanochemical activation of carbonate raw materials.

\section{Methods of research}

As an indicator of the energy state of the surface, the lyophility index $\beta_{n}$ is used in the work, which is the ratio of the cosine of the wetting angle of the powder material with water to the cosine of the wetting angle of this material by xylene. The values of the wetting angles are determined according to the thin-layer capillary impregnation technique described in [11].

To characterize the interaction between the calcite surface and modifiers, infrared spectroscopy is used, the informativity of which in this case is determined by the suitability for identifying chemical interactions in the system, as well as the weaker interactions of the Van der Waals and hydrogen types. The spectrograms are obtained on a Specord IR-75 device (Germany) in powder form with $\mathrm{KBr}$ as a spectrally transparent carrier.

To assess the change in the crystal structure of the material, X-ray diffraction analysis is used. The diffraction patterns are obtained on а ДРОН-3 instrument (USSR).

The interaction between the silicone film former and the modified calcite is evaluated by the viscosimetry method on the Rheotest II (Germany). When interpreting the results, it is assumed that the strength of the coagulation structure of calcite dispersions in the binder solution correlates with the degree of non-chemical interaction of the particle surface with macromolecular chains.

For the study, two grades of sedimentary calcite are selected: ММС-2 and МТД manufactured by Sumyagroprombud PJSC, Ukraine. Mechanochemical treatment of materials is carried out in a ball mill with ceramic balls.

A number of organosilicon liquids are used to modify the material: sodium and potassium methylsiliconates (ГКЖ 11-К and ГКЖ-11 H, manufactured by SEZ «Kremnypolymer», Ukraine), polymethylhydride siloxane liquid $134-41 \mathrm{~m}$ of the same manufacturer.

\section{Research results}

It has been established that the hydrophilicity degree of the surface of the initial materials differs significantly: МТД material (Fig. 1, $a$ ) has a more hydrophilic surface in comparison with MMC-2 (Fig. 2). This is expressed in the values of $\beta_{n} 0.32$ and 0.56 , respectively. The relative error in determining this indicator is $3 \%$.

The nature of the dependence of the $\beta_{n}$ index on the modifier concentration, however, is similar in both materials: the most effective is polymethylhydride siloxane, and the least is sodium methylsiliconate. The lowest values of $\beta_{n}$ that can be achieved with the use of the polymethylhydride siloxane modifier are 0.04 and 0.11 , respectively.

Comparison of surface activity of two grades of sedimentary calcite indicates the presence of a more active surface in ММC-2 material compared to МТД. Taking into account the close values of the average particle size $(2.5$ and $3 \mu \mathrm{m}$, respectively), it is possible to assume the presence of increased amounts of submicron impurities in MMC-2 material. This feature is a negative factor, which should be avoided when choosing filler for paint and varnish material. It determines the choice of the material for МТД for further research. 


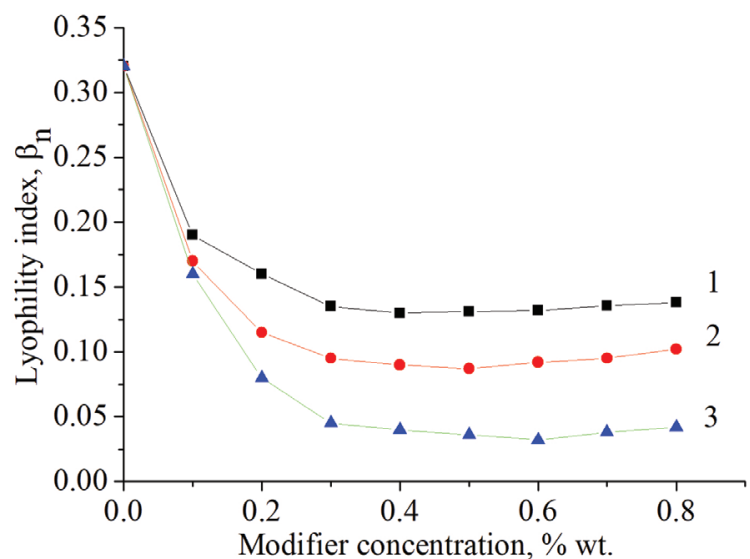

a

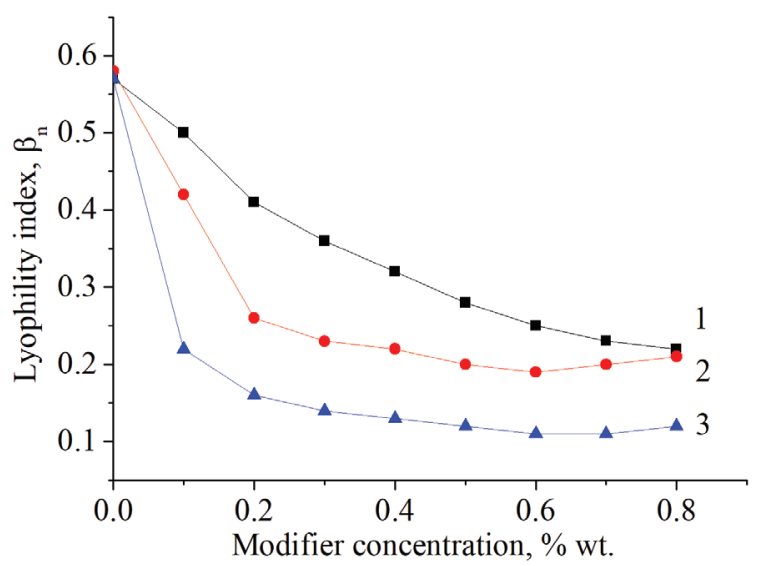

$b$

Fig. 1. Dependence of the lyophility index $\beta_{n}$ on the modifier concentration in the mechanochemical activation of calcites:

a - МТД; $b$ - ММС-2; 1 - sodium methylsiliconate; 2 - potassium methylsiliconate; 3 - polymethylhydride siloxane liquid

It is obvious that polymethylhydride siloxane is a more effective modifier of the calcite surface. This fact is also confirmed by the data of infrared spectroscopy, namely, the intensity of the absorption band of stretching vibrations of the $\mathrm{O}-\mathrm{H}$ bond by the adsorbed surface of the water mineral $\left(3420 \mathrm{~cm}^{-1}\right)$. In the case of polymethylhydride siloxane, it rises to $10 \%$ in comparison with the intensity of this band in unmodified material, and in the case of sodium and potassium methylsiliconates - by 27 and $22 \%$, respectively. This fact can be explained by the hydrolysis of unbound functional groups of modifiers on the mineral surface upon completion of the second and subsequent adsorption layers. A similar mechanism is described, for example, in [12].

During the grinding, the modifiers play the role of surface active substances, which is confirmed by the appearance of the Rebinder effect in such systems, accompanied by an increase in the dispersion efficiency. This is clearly seen in the analysis of the intensity of four characteristic reflections of the crystal lattice of calcite $(0.3346,0.3035$, 0.2281 and $0.1874 \mathrm{~nm}$ ) (Fig. 2).

As can be seen from Fig. 2, the greatest amorphization degree of calcium carbonate can be achieved with the use of polymethylhydride siloxane and sodium methyl siliconate. When using potassium methylsiliconate, the Rebinder effect is less weakly expressed.

In order to confirm the effectiveness of the effect of modifying calcite on the processes of its surface interac- tion with polymethylphenylsiloxane, the process of adsorption of this film former under dynamic conditions is studied (Fig. 3).
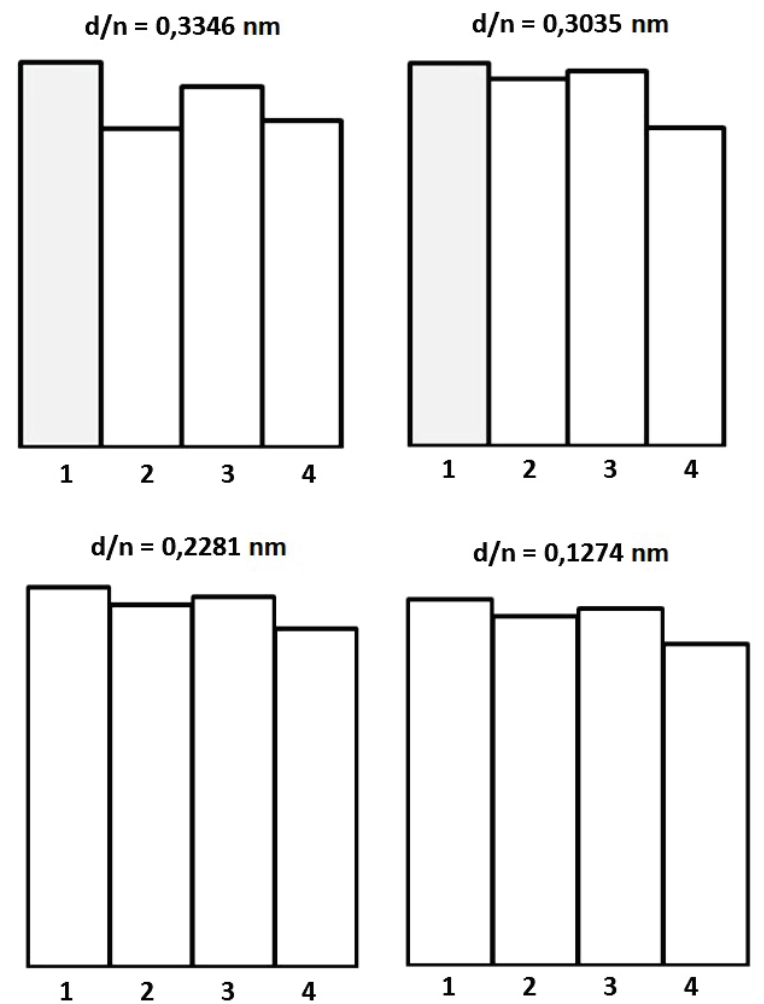

Fig. 2. Relative change of characteristic maxima of МТД calcite on X-ray diffraction patterns: 1 - without modifier; 2 - sodium methylsiliconate;

3 - potassium methylsiliconate; 4 - polymethylhydride siloxane

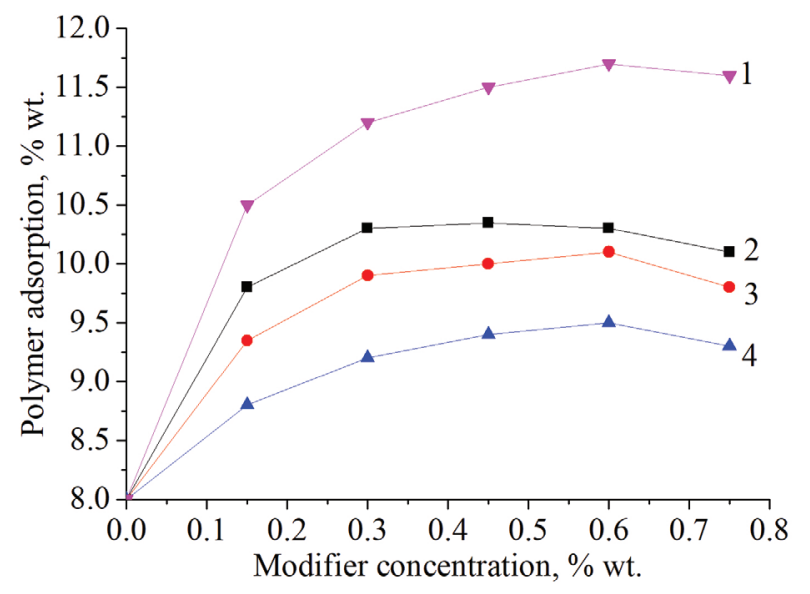

Fig. 3. Adsorption of polymethylphenyl siloxane with modified sedimentary МТД calcite: 1 - without modifier; 2 - potassium methylsiliconate;

3 - sodium methylsiliconate; 4 - polymethylhydrid esiloxane

The adsorption curves in Fig. 3 make it possible to trace the change in the calcite capacity with respect to the film former, depending on the energy state of the surface of this filler. The unmodified polar surface is characterized by the maximum equilibrium adsorption at the level of $11.75 \mathrm{wt} \%$, and lyophilized by treatment with polymethylhydride siloxane -9.4 wt. \%. It is obvious that processing of the raw mineral with this filler allows to reduce the amount of polymer in the adsorption shells, and to increase the 
filling degree of the paint material due to this. In general, this will lead to decrease in the cost of the latter.

The use of the modifier also determines the rheological characteristics of the material dispersions (Table 1).

Table 1

Bheological characteristics of 50 wt. \% of dispersions of modified calcite in a solution of polymethylphenylsiloxane

\begin{tabular}{|c|c|c|c|c|}
\hline \multirow{2}{*}{ Modifier } & \multicolumn{2}{|c|}{ Static } & \multicolumn{2}{c|}{ Dynamic } \\
\cline { 2 - 5 } & $\begin{array}{c}\text { Yield } \\
\text { strength, } \\
Y_{s_{1}}, \mathrm{~Pa}\end{array}$ & $\begin{array}{c}\text { Vis- } \\
\text { cosity, } \\
\eta^{\circ}, \mathrm{Pa} \cdot \mathrm{s}\end{array}$ & $\begin{array}{c}\text { Yield } \\
\text { strength, } \\
Y_{s_{2}}, \mathrm{~Pa}\end{array}$ & $\begin{array}{c}\text { Vis- } \\
\text { cosity, } \\
\eta^{*}, \mathrm{~Pa} \cdot \mathrm{s}\end{array}$ \\
\hline Without modifier & 117.7 & 44.3 & 527.1 & 6.8 \\
\hline Sodium methylsiliconate & 107.4 & 35.7 & 493.8 & 5.7 \\
\hline Potassium methylsiliconate & 112.5 & 42.1 & 507.6 & 6.2 \\
\hline Polymethylhydride siloxane & 93.4 & 28.7 & 480.3 & 4.5 \\
\hline
\end{tabular}

Due to a decrease in the ability of particles to form solvate shells during processing with modifiers, the strength of the coagulation structure of their dispersions decreases. And consequently, the values of rheological indicators. This is most effective in the case of polymethylhydride siloxane. The data of this research confirm the previous results on the effect of mechanochemical treatment of the calcite surface on its interaction with the silicone film former.

\section{SWOT analysis of research results}

Strengths. Among the strengths of this research, it is necessary to note the obtained results, based on a comparative assessment, of the mechanochemical modification of sedimentary calcite of Ukrainian deposits. This conclusion is supported by the results of the analysis of modern scientific periodicals given above, from which the possibility of using effective organosilicon modifiers becomes evident, but at the same time the question of the comparative degree of changes in the properties of the calcite surface depending on the functionality of siloxanes is not considered. The use of the obtained data makes it possible to flexibly regulate the required surface energy of activated carbonates depending on the input parameters: the specific surface area and the lyophility index of the raw material.

Weaknesses. The weaknesses of this research are related to the fact that the choice of the range of modifiers for consideration is rather narrow, for example, there are no widely used aminosilanes for these purposes. In addition, the market value of organosilicon modifiers is 1.7-2.0 times higher than the cost of traditional fatty acid-based additives. These problems can partly be solved by optimizing the concentration of the modifier, given its increased efficiency.

Opportunities. Opportunities for direction of this research lie in the prospect of obtaining a theoretical basis for selecting the modifier-film forming pair or for selecting a filler additive for the filler in systems with a certain polymer matrix. This can be used not only in the paint and varnish industry, but also in the industries of adhesives, sealing compounds and processing of polymer melts.

The use of mechanical activation together with chemical modification makes it unnecessary to pre-treat the filler and to achieve results within the existing process. As a consequence, with the introduction of technology in paint production enterprises, it is possible to use Ukrainian raw materials in the form in which they are supplied by the manufacturer. In turn, this allows to reduce the cost of the finished product without a significant change in the technological scheme.

Threats. In the future, the difficulties in implementing the research results are related to the almost complete reduction in the production of organosilicon modifiers in Ukraine, which will negatively affect the cost of the product. However, in general, the expected increase in the cost of modified filler will not be more than $1.75-2.5 \%$. In the total cost of the product, this figure will be even smaller. This disadvantage can be compensated for by adjusting the existing recipes in the direction of increasing the filler content by $5-7 \%$ of the original. Such solution becomes possible in view of a decrease in the capacitance of the calcite surface with respect to the binder.

Despite the advantages of the proposed technical improvement, it is likely that the use of traditional fatty acidbased materials will remain more attractive in continuous production. Since this method has advantages from the point of view of the absence of the need to change the existing composites formulations, and from the point of view of minimizing the cost price. Research results will be more interesting in those industries where improving the properties of the material plays a decisive role.

\section{Conclusions}

1. It is found that during the mechanochemical activation in the presence of organosilicon modifiers, the hydrophilicity index of the surface of the sedimentary chalk is significantly reduced:

- for a pair of polymethylhydride siloxane - МТД chalk from 0.35 to 0.04 ;

- for a pair of polymethylhydride siloxane MMC-2 chalk from 0.57 to 0.11 .

The effective concentrations of most modifiers are in this range in the range $0.2-0.4 \mathrm{wt}$. \%. The most effective modifier for the surface of sedimentary calcite is polymethylhydride siloxane. For example, the minimum attainable value of $\beta_{n}$ for MTD chalk of this modifier is 0.04 , for sodium and potassium methyl silicates -0.13 and 0.09 respectively

2. It is established that in the presence of modifiers, grinding and amorphization of the carbonate raw material is activated. This is confirmed by a decrease in the intensity of the reflexes $(0.3346,0.3035,0.2281$ and $0.1874 \mathrm{~nm})$ of calcite to $9 \%$ in the case of the use of polymethylhydride siloxane and by $5-7 \%$ in the case of the use of methyl siliconates.

3. It is shown that the modification of the surface of the sedimentary chalk leads to a decrease in the capacity of its adsorption layer by $20 \%$ of the capacity of the processed material. Also, the strength of the coagulation structure in the filler-film former system decreases: the yield point of the system with raw material is $20 \%$ higher than this limit for the system where chalk is modified with polymethylhydride siloxane.

\section{References}

1. Mihajlovic, S. Surface properties of natural calcite filler treated with stearic acid [Text] / S. Mihajlovic, Z. Sekulic, A. Dakovic, D. Vucinic // Ceramics - Silikaty. - 2009. - Vol. 53, No. 4. - P. 268-275. 
2. Diedel, R. Identification and modification of the surface properties of calcite fillers as a basis for new, highly filled adhesives [Text] / R. Diedel, H. Dorr, P. L. Geiß, M. Presser // Geotechnologien Science Report. - 2010. - No. 16. - P. 96-110.

3. Deshmukh, G. S. Effect of uncoated calcium carbonate and stearic acid coated calcium carbonate on mechanical, thermal and structural properties of poly(butylene terephthalate) (PBT)/calcium carbonate composites [Text] / G. S. Deshmukh, S. U. Pathak, D. R. Peshwe, J. D. Ekhe // Bulletin of Materials Science. - 2010. - Vol. 33, No. 3. - P. 277-284. doi:10.1007/ s12034-010-0043-7

4. Mihajlovic, S. R. Mechanism of stearic acid adsorption to calcite [Text] / S. R. Mihajlovic, D. R. Vucinic, Z. T. Sekulic, S. Z. Milicevic, B. M. Kolonja // Powder Technology. - 2013. Vol. 245. - P. 208-216. doi:10.1016/j.powtec.2013.04.041

5. Zhang, J. Chemical Surface Modification of Calcium Carbonate Particles by Maleic Anhydride Grafting Polyethylene Wax [Text] / J. Zhang, J. Guo, T. Li, X. Li // International Journal of Green Nanotechnology: Physics and Chemistry. - 2010. Vol. 1, No. 2. - P. 65-71. doi:10.1080/19430871003684341

6. Zhiyuan, Y. Surface modification of $\mathrm{CaCO} 3$ nanoparticles with silane coupling agent for improvement of the interfacial compatibility with styrene-butadiene rubber (SBR) latex [Text] Y. Zhiyuan, T. Yanjun, Z. Junhua // Chalcogenide Letters. 2013. - Vol. 10, No. 4. - P. 131-141.

7. Nakatsuka, T. Functional silane-modified calcium carbonate [Text] / T. Nakatsuka, H. Kawasaki, K. Itadani, S. Yamashita // Journal of Applied Polymer Science. - 1979. - Vol. 24, No. 9. P. 1985-1995. doi:10.1002/app.1979.070240906

8. Ding, H. Mechano-activated surface modification of calcium carbonate in wet stirred mill and its properties [Text] / H. Ding, S. Lu, Y. Deng, G. Du // Transactions of Nonferrous Metals Society of China. - 2007. - Vol. 17, No. 5. - P. 1100-1104. doi:10.1016/s1003-6326(07)60232-5

9. Cao, Z. Chemical surface modification of calcium carbonate particles with stearic acid using different treating methods [Text] Z. Cao, M. Daly, L. Clemence, L. M. Geever, I. Major, C. L. Higginbotham, D. M. Devine // Applied Surface Science. - 2016. Vol. 378. - P. 320-329. doi:10.1016/j.apsusc.2016.03.205

10. Gutman, E. M. Mechanochemistry of Solid Surfaces [Text] / E. M. Gutman. - Singapore: World Scientific Publishing Company, 1994. - 332 p. doi:10.1142/9789814354066 fmatter

11. Cui, Z.-G. Determination of Contact Angles on Microporous Particles Using the Thin-Layer Wicking Technique [Text] /
Z.-G. Cui, B. P. Binks, J. H. Clint // Langmuir. - 2005. Vol. 21, No. 18. - P. 8319-8325. doi:10.1021/la0510578

12. Blagojevic, S. L. Silane pre-treatment of calcium carbonate nanofillers for polyurethane composites [Text] / S. L. Blagojevic, V. Kovacevic, M. Leskovac, D. Vrsaljko // e-Polymers. 2004. - Vol. 4, No. 1. - P. 14. doi:10.1515/epoly.2004.4.1.384

\section{ИССЛЕДОВАНИЕ ЛРОЦЕССА МОДИФИКАЦИИ ПРИРОДНОГО ОСАДОЧНОГО КАЛЬЦИТА КРЕМНИЙОРГАНИЧЕСКИМИ СОЕДИНЕНИЯМИ}

Установлено, что в ходе механохимической активации в присутствии кремнийорганических модификаторов коэффициент гидрофильности поверхности осадочного мела снижается. Установлено, что в присутствии модификаторов активизируется аморфизация карбонатного сырья. Доказано, что модификация поверхности осадочного мела приводит к снижению емкости адсорбционного слоя. Определено, что при модификации снижается прочность структуры в системе наполнитель-плёнкообразователь.

Ключевые слова: система наполнитель-плёнкообразователь, осадочный кальцит, механохимическая активация кремнийорганическими соединениями.

Arshynnikov Dmytro, Applicant, Department of Chemical Technology of Composition Materials, National Technical University of Ukraine «Igor Sikorsky Kyiv Polytechnic Institute», Ukraine, e-mail: igorlkm@ukr.net, ORCID: http://orcid.org/0000-0002-7874-4830

Sviderskiy Valentin, Doctor of Technical Sciences, Professor, Department of Chemical Technology of Composition Materials, National Technical University of Ukraine «Igor Sikorsky Kyiv Polytechnic Institute»,Ukraine, e-mail: htum@Dkpi.ua,ORCID: http://orcid.org/ 0000-0002-2246-3896

Myronyuk Oleksiy, PhD, Associate Professor, Department of Chemical Technology of Composition Materials, National Technical University of Ukraine «Igor Sikorsky Kyiv Polytechnic Institute», Ukraine, e-mail: whizershines@gmail.com, ORCID: http://orcid.org/00000003-0499-9491

Baklan Denis, Department of Chemical Technology of Composition Materials, National Technical University of Ukraine «Igor Sikorsky Kyiz Polytechnic Institute»,Ukraine, e-mail: denisbaklan1kpi@gmail.com, ORCID: http://orcid.org/0000-0002-6608-0117 